\title{
Efficacy of the Basic Trauma Course in Family Medicine Resident Physicians in Southern Ecuador: It is Time to Innovate Education in Trauma
}

\author{
Juan F Figueroa ${ }^{1}$, Christian Loyola², Fray Martínez ${ }^{3}$, Juan C Salamea ${ }^{4}$
}

\begin{abstract}
Introduction: In Ecuador, as in other Latin American countries, trauma has become one of the main reasons to seek medical care in the country. According to data obtained from the National Institute of Statistics and Censuses (INEC), the rate of homicides, car accidents, suicides, and burns, grouped together, represent the main cause of morbidity and mortality in people aged between 18 years and 40 years, surpassing mortality due to cardiovascular causes or diabetes. Additionally, one study on geolocation of calls made to the emergency services (SIS-ECU 9-1-1) indicated that trauma in the country is becoming more and more frequent in marginal urban and rural areas, where health services are scarce. Due to this emerging situation, it is necessary to evaluate the short- and long-term effectiveness of the Basic Trauma Course (BTC), a course designed to educate students, general practitioners, prehospital staff and primary healthcare physicians.

Objective: To evaluate the effect of the BTC in family medicine residents who work in Health Centers in marginalurban and rural areas of the Azuay, Cañar, and Morona Santiago provinces in southern Ecuador.

Materials and methods: Quasi-experimental study in which knowledge is evaluated at three stages in time (before the course, at the end of the course and one year later) in 39 family medicine residents. Comparison of means of the test scores was made using formulas in SPSS of analysis of variance (ANOVA) and Tukey HSD.

Results: ANOVA brought significant differences between measurements $(F=8.38, p$ value $<0.0005)$. The increase in the score between the pretest and the immediate posttest was significant ( $p$ value $<0.01$ ). The difference between pretest and late posttest was not significant. The comparison of the immediate and late posttest results showed a decrease in the mean, being statistically significant ( $p$ value $<0.01)$.

Conclusion: The BTC, as a unique training course, does not guarantee the permanence of long-term knowledge in participants who do not regularly attend to the trauma patient, requiring constant training using spaced repetition methods, for adequate consolidation.
\end{abstract}

Keywords: Basic trauma course, Global surgery, Prevention, Trauma education.

\section{Resumen}

Introducción: En el Ecuador, al igual que en otros países de latinoamerica, el trauma se ha convertido en una de las principales causas de atención médica en el país. Según cifras del Instituto Nacional de Estadísticas y Censos (INEC), la tasa de homicios, accidentes automovilísticos, suicidios y quemaduras, agrupadas, representan la principal causa de morbilidad y mortalidad en personas entre 18 y 40 años, sobrepasando la mortalidad por causas cardiovasculares o diabetes. Adicionalmente, estudios sobre geolocalización de llamadas al sistema único de emergencia (SIS-ECU 9-1-1), indican que el trauma en el país se vuelve cada vez más frecuente en zonas urbano-marginales y rurales, en donde los servicios de salud son escasos. Debido a esta situación emergente, es necesario evaluar la efectividad a corto y largo plazo del Curso Básico de Trauma (BTC), un curso proyectado a educar a estudiantes, médicos generales, personal prehospitalario y médicos de atención primaria de salud.

Objetivo: Evaluar el efecto del curso básico de trauma en médicos postgradistas de medicina familiar que laboran en Centros de Salud de zonas urbano-marginales y rurales de las provincias Azuay, Cañar y Morona Santiago, en el sur del Ecuador.

Métodos: Es un estudio cuasi-experimental en donde se evaluan los conocimientos en tres momentos (antes del curso, al finalizar el curso y un año más tarde) en 39 postgradistas de medicina familiar. Se realizó comparación de medias de los puntajes de los test utilizando fórmulas en SPSS de ANOVA y Tuckey HSD.

Resultados: El ANOVA dio diferencias significativas entre las mediciones $(F=8.38, p<0.0005)$. El incremento del puntaje entre el pre-test y el postest inmediato fue significativo $(p<0,01)$. La diferencia entre pre-prueba y post-prueba tardía resultó no significativa. La comparación de los resultados de post-prueba inmediata y tardía mostró disminución del promedio siendo estadísticamente significativo $(p<0.01)$.

Conclusión: El BTC, como curso de capacitación único, no garantiza la permanencia del conocimiento a largo plazo en los participantes que no atienden regularmente al paciente de trauma, siendo necesario realizar capacitaciones constantes mediante métodos de repetición espaciada, para una consolidación adecuada.

Palabras claves: Curso Básico de Trauma, BTC, Prevención, Atención primaria, Trauma, Educación.

Panamerican Journal of Trauma, Critical Care \& Emergency Surgery (2020): 10.5005/jp-journals-10030-1286

\section{INTRODUCTION}

Trauma, grouped in all its possible etiologies, is the main cause of death in people younger than 40 years. According to statistics obtained from the Emergency Medical Services (EMS) of the city of Cuenca in 2011, it was found that $83 \%$ of those affected are young

\footnotetext{
${ }^{1-3}$ Faculty of Medicine, Universidad del Azuay, Cuenca, Azuay, Ecuador

${ }^{4}$ Faculty of Medicine, Universidad del Azuay, Cuenca, Azuay, Ecuador; Department of Trauma Surgery, Hospital Vicente Corral Moscoso, Cuenca, Azuay, Ecuador
}

() The Author(s). 2020 Open Access This article is distributed under the terms of the Creative Commons Attribution 4.0 International License (https://creativecommons. org/licenses/by-nc/4.0/), which permits unrestricted use, distribution, and non-commercial reproduction in any medium, provided you give appropriate credit to the original author(s) and the source, provide a link to the Creative Commons license, and indicate if changes were made. The Creative Commons Public Domain Dedication waiver (http://creativecommons.org/publicdomain/zero/1.0/) applies to the data made available in this article, unless otherwise stated. 
people between the ages of 1 and 40 years, most likely due to motor vehicle accidents, interpersonal violence, followed by occupational injuries, and suicide, among others, while $27 \%$ of trauma patients are people aged 40 years and older. ${ }^{1,2}$

In all, $84 \%$ of the trauma calls received to the SIS ECU 9-1-1 in Cuenca come from urban territories; however, $16 \%$ come from marginalurban and rural areas, where healthcare centers are scarce and have limited resources, resulting in a possible deficient approach in the prehospital setting, which could be more effective with the training of first-level healthcare physicians in rural areas, such as in the Ecuadorian Amazon. 3,4

Additionally, it must be taken into account that there are deficiencies in the communication and transfer systems to a more complex center, delaying the arrival to more prepared hospitals. ${ }^{3,4}$

In 2003, Aboutanos and Rodas evidenced a deficiency in trauma systems among healthcare personnel of the southern Amazon region of Ecuador and concluded that different factors could have influenced, the most important being lack of education. Trauma courses were held for 2 years in order to educate and strengthen knowledge in healthcare personnel. ${ }^{4}$

The Basic Trauma Course (BTC) is an educational program that covers different theoretical/practical topics of evaluation and initial management of the trauma patient in places, where resources are limited and the accessibility of courses such as Advanced Trauma Life Support (ATLS) is not possible, like the rural areas of our country, becoming a suitable course for low- and middle-income countries (LMIC). ${ }^{4}$

Nowadays, with the emerging situation and increase in trauma, it is necessary for the primary care physicians to receive adequate training in trauma, beyond first aid courses; at the same time, it is important to evaluate the efficacy of the training courses to analyze their results and identify their strengths and weaknesses. ${ }^{5-11}$

\section{Materials and Methods}

A quasi-experimental study was carried out with three evaluations separated in time: one test before the theoretical/practical course, a posttest immediately after concluding the course, and another test after 12 months.

The participants of this study were family medicine resident physicians ( $n=39$ ) who attended the BTC. The exclusion criteria were determined by lack of participation in any of the three tests of the course. One participant was excluded.

The course was given by members of the Panamerican Trauma Society (PTS) and students of the local trauma league of Ecuador. The curriculum was fragmented in:

- Twenty four hours of lectures (initial evaluation and management of the trauma patient, triage and team approach, airway management, chest trauma, shock and resuscitation, abdominal and pelvic trauma, skeletal muscle trauma, neurotrauma,
Corresponding Author: Juan F Figueroa, Faculty of Medicine, Universidad del Azuay, Cuenca, Azuay, Ecuador, Phone: +593 994154 515, e-mail: juanfigueroacordero@gmail.com

How to cite this article: Figueroa JF, Loyola C, Martínez F, et al. Efficacy of the Basic Trauma Course in Family Medicine Resident Physicians in Southern Ecuador: It is Time to Innovate Education in Trauma. Panam J Trauma Crit Care Emerg Surg 2020;9(2):97-100.

Source of support: Universidad del Azuay

Conflict of interest: None

thermal injuries, pediatric trauma, geriatric trauma, and obstetric trauma)

- Four hours of clinical simulations and moulage (airway management, initial management in chest trauma, initial management of multi-trauma patients in critical situations such as penetrating injuries, falls, burns and traffic accidents.

- Two hours for tests.

The test was endorsed by the PTS and consisted of 3 prehospital management $(\mathrm{PH})$ questions, 24 primary survey questions, and 3 secondary review (SR) questions, for a total of 30 points. In order to pass the test, the minimum score is $60 \%(18 / 30)$.

Data collection was processed and analyzed with SPSS 22 software. The means were compared using analysis of variance (ANOVA) and Tukey HSD.

\section{Results}

In all, 39 participants who were family medicine residents received the course and took different tests.

At the time of the pretest, the mean score was $80 \%$ (23.9/30). One student failed the test with $56 \%$ (17/30), while in both posttests all students passed with more than $60 \%$ of the score, with a mean of $85 \%(25.5 / 30)$ in the immediate posttest and $79.5 \%(23.8 / 30)$ after 1 year (Table 1$)$.

When performing the ANOVA of repeated measures, a statistically significant difference between the measurements was demonstrated $(F 8.38, p$ value $<0.0005)$.

To assess the specific differences between the groups, the Tukey HSD post hoc test was used; a significant difference was found between the first and second moment (HSD 1.14, $p$ value $<0.01$ ) and between the second and third moment (HSD 1.43, $p$ value $<0.01$ ). In the first case, the result showed a higher level and, in the second, the difference was in favor of the deterioration of knowledge. The comparison between the mean of the pretest and the posttest 12 months later did not show significant differences.

The percentage distribution of correct answers was identified at the three different moments of the evaluation (Table 2).

Segments D (neurological deficit), E (exposure), and PH (prehospital) in the late posttest maintained a higher level than the pretest.

Table 1: Results of statistical analysis with ANOVA and Tuckey HSD in repeated measures

\begin{tabular}{llllllll}
\hline & & & \multicolumn{5}{c}{ ANOVA repeated } \\
Test & $N$ & Mean & SD & Min & Max & measures & $p$ \\
\hline Pretest & 39 & 23.97 & 2.59 & 17 & 28 & $F(2.76)=8,38$ & $<0.001$ \\
Immediate posttest & 39 & 25.53 & 1.86 & 20 & 28 & Tukey HSD & $p$ \\
Posttest 12 m later & 39 & 23.87 & 2.05 & 20 & 28 & P1 vs P2 & $<0.01$ \\
& & & & & & P1 vs P3 & NS \\
& & & & & & P2 vs P3 & $<0.01$ \\
\hline
\end{tabular}


Table 2: Score percentage of the different segments of the test in the three different stages

\begin{tabular}{llll}
\hline & Pretest (\%) & Posttest I (\%) & Posttest II (\%) \\
\hline A & 66.6 & 72.6 & 64.95 \\
B & 68.8 & 79.48 & 66.6 \\
C & 90.02 & 92.8 & 88.3 \\
D & 94.87 & 100 & 100 \\
E & 89.74 & 96.1 & 92.3 \\
PH & 94.87 & 92.3 & 95.72 \\
RS & 53.84 & 61.5 & 52.99 \\
\hline
\end{tabular}

\section{Discussion}

The family medicine resident physicians demonstrated an adequate knowledge in trauma before the course with a mean of $79 \%$, with only one student failing the test, which could have been associated with the constant learning curriculum of their career. ${ }^{12,13}$

After taking the course, the students were able to maximize their knowledge, and their test scores increased to a mean of $85 \%$ of correct answers, proving the short-term effectivity of the course despite the complexity and the high workload in a restricted period of time.

We could determine that presenting the same topics in different learning models like lectures, videos, and clinical case simulations could be helpful to enhance the consolidation in the short-term, turning into a remarkable strength of the course..$^{12,13}$

Nonetheless, when we evaluated the long-term effect after 1 year, we found that there was a cognitive decline with similar results as before the course reflecting a main weakness. ${ }^{12-17}$ Some studies have found similar data with the ATLS course, where cognitive decline became evident at 6 months in physicians who work in a clinical specialty, compared to surgeons where cognitive decline became evident 2 years later after the course. ${ }^{18-21}$

As the BTC's main audience are nonsurgical-related healthcare workers, it is important to innovate the learning techniques to promote maintenance of knowledge by using method of spaced repetition, such as Anki App, Journal Clubs, multimedia, questionnaires, or continuous medical education courses. ${ }^{22}$

\section{Conclusion}

When analyzing the results obtained in this work, we can conclude that training in trauma with the BTC has a statistically significant result, improving their knowledge immediately but limited to the short-term only.

It is necessary to promote a change in the curriculum in order to encourage continuous education or the use of spaced repetition tools to obtain better results in education. ${ }^{11,22}$

Further studies are required to obtain a broader sample, which allows us to avoid limitations such as type B error, by strengthening the statistical power. In addition, it is necessary to evaluate other groups of students to improve the external validity of the study.

\section{References}

1. American College of Surgeons Committee on Trauma. Advanced Trauma Life Support Student Course Manual. Chicago, IL: American College of Surgeons; 2012.

2. Sarmiento G, Sarmiento V, Martínez F, et al. Comportamiento del Proceso Prehospitalario ante la Llamada de Auxilio Por trauma, CsC911, 2011. Panam J trauma, Crit Care Emerg Surg 2012. 168-174. http://
www.jaypeejournals.com/eJournals/ShowText.aspx?ID=4314\&Type $=F R E E \& T Y P=T O P \& I N=\_$eJournals/images/JPLOGO.gif $\& I I D=336 \&$ Val $\mathrm{ue}=30$ \&isPDF $=$ YES.

3. Salamea JC, Sacoto H, Rodas EB, et al. Emergencias en el Sur del Ecuador; Historia, Realidad Y Perspectivas. Panam J trauma. Crit Care Emerg Surg 2014;3(2):73-75. http://www.jaypeejournals.com/ eJournals/ShowText.aspx?ID=6475\&Type=FREE\&TYP=TOP\&IN= / eJournals/images/JPLOGO.gif\&IID=488\&isPDF=YES.

4. Aboutanos MB, Rodas EB, Aboutanos SZ, et al. Trauma education and care in the jungle of Ecuador, where there is no advanced trauma life support. J Trauma 2007;62(3):714-719. DOI: 10.1097/TA.0b013e318031b56d. http://www.ncbi.nlm.nih.gov/ pubmed/17414353.

5. World Health Organization. The Injury Chart Book: a Graphical Overview of the Global Burden of Injuries. Geneva: World Health Organization Department of Injuries and Violence Prevention. Noncommunicable Diseases and Mental Health Cluster; 2002.

6. Mock C, Joshipura M, Arreola-Risa C, et al. An estimate of the number of lives that could be saved through improvements in trauma care globally. World J Surg 2012;36(5):959-963. DOI: 10.1007/s00268-0121459-6.

7. Instituto Nacional de Estadísticas y Censos. Anuario de Estadísticas Vitales: Nacimientos y Defunciones; 2013. Internet: http://www. ecuadorencifras.gob.ec/documentos/web-inec/Poblacion_y_ Demografia/Nacimientos_Defunciones/Publicaciones/Anuario_ Nacimientos_y_Defunciones_2011.pdf.

8. Carolina D, León V. Trauma en base a los reportes de los principales diarios de la ciudad de Cuenca. 2014.

9. Rogers FB, Shackford SR, Hoyt DB, et al. Trauma deaths in a mature urban vs rural trauma system. A comparison. Arch Surg 1997;132(4):376-381. DOI: 10.1001/archsurg.1997.01430280050007; discussion 381-2.

10. Ozgediz D, Jamison D, Cherianc $M$, et al. The burden of surgical conditions and access to surgical care in low and middle-income countries. Bull World Health Organ 2008;86(8):646-647. DOI: 10.2471/ BLT.07.050435.

11. Simões RL, Bermudes FAM, Andrade HS, et al. Trauma leagues: an alternative way trauma to teach surgery to medical students. Rev Col Bras Cir 2014;41(4):297-302. DOI: 10.1590/0100699120140040013. http://www.scielo.br/scielo.php?script=sci_artt ext\&pid=S0100-69912014000400297.

12. Amiri H, Gholipour C, Mokhtarpour M, et al. Two-day primary trauma care workshop: early and late evaluation of knowledge and practice. Eur J Emerg Med 2013;20(2):130-132. DOI: 10.1097/ MEJ.0b013e32835608c6.

13. Delgado-Reyes L, Gasca-González OO, Delgado-Guerrero F, et al. Effectiveness of trauma evaluation and management course for mexican senior medical students: when to implement it? Cir Cir 2015;84(3):220-224. http://www.sciencedirect.com/science/article/ pii/S0009741115002376.

14. Ortiz Figueroa F, Moftakhar Y, Dobbins Iv AL, et al. Trauma boot camp: a simulation-based pilot study. Cureus 2016;8(1):e463. DOI: 10.7759/ cureus.463.

15. Peter N, Pandit $H$, Le G, et al. Delivering a sustainable trauma management training programme tailored for low-resource settings in east, central and Southern African countries using a cascading course model. Injury 2015;47(5):1128-1134. DOI: 10.1016/j. injury.2015.11.042.

16. Bergman $S$, Deckelbaum $D$, Lett $R$, et al. Assessing the impact of the trauma team training program in Tanzania. J Trauma 2008;65(4): 879-883. DOI: 10.1097/TA.0b013e318184a9fe.

17. Pemberton J, Rambaran M, Cameron BH. Evaluating the long-term impact of the trauma team training course in Guyana: an explanatory mixed-methods approach. Am J Surg 2013;205(2):119-124. DOI: 10.1016/j.amjsurg.2012.08.004.

18. Jayaraman S, Mabweijano JR, Lipnick MS, et al. First things first: effectiveness and Scalability of a basic prehospital trauma care program for lay first-responders in Kampala, Uganda. PLoS One 2009;4(9):e6955. DOI: 10.1371/journal.pone.0006955. 
19. Blumenfeld $A$, Ben Abraham R, Stein $M$, et al. Cognitive knowledge decline after advanced trauma life support courses. J Trauma 1998;44(3):513-516. DOI: 10.1097/00005373-199803000-00017.

20. Ali J, Howard M, Williams I. Do factors other than trauma volume affect attrition of ATLS-acquired skills? J Trauma 2003;54(5):835-841. DOI: 10.1097/01.TA.0000057233.97051.81.
21. Mohammad A, Branicki F, Abu-Zidan FM. Educational and clinical impact of advanced trauma life support (ATLS) courses: a systematic review. World J Surg 2014;38(2):322-329. DOI: 10.1007/s00268-0132294-0.

22. Augustin M. How to learn effectively in medical school: test yourself, learn actively, and repeat in intervals. Yale J Biol Med 2014;87(2):207. 